\title{
MARJANE SATAPRI E A ARTE DE ILUSTRAR: DISCURSO HISTÓRICO E AUDIOVISUAL
}

ELIANE MEIRE SOARES PONTIFÍCIA UNIVERSIDADE CATÓLICA DO RIO GRANDE DO SUL BELO HORIZONTE, MINAS GERAIS, BRASIL E-MAIL: ELIANEST2002@YAHOO.COM.BR

JANIE KISZEWSKI PONTIFÍCIA UNIVERSIDADE CATÓLICA DO RIO GRANDE DO SUL BELO HORIZONTE, MINAS GERAIS, BRASIL E-MAIL: JANIEKPACHECO@YAHOO.COM.BR

TAMMIE CARUSE FARIA PONTIFÍCIA UNIVERSIDADE CATÓLICA DO RIO GRANDE DO SUL BELO HORIZONTE, MINAS GERAIS, BRASIL E-MAIL: TAMMIE.FARIA@GMAIL.COM 
MARJANE SATAPRI E A ARTE DE ILUSTRAR: DISCURSO HISTÓRICO E AUDIOVISUAL

Resumo: Tratarmos os efeitos e a estética sonora no cinema de animação com o trailer Persépolis disponibilizado na internet. $O$ vídeo tem como base a novela gráfica produzida pela iraniana Marjane Satapri através de HQs História em Quadrinhos para o público adulto. Analisamos a memória através do discurso utilizado pela autora, torna-se personagem de sua história, aborda sua infância no período da Revolução Islâmica. História de refúgio e repressão.

Palavras-chave: Análise de Discurso; Cinema de animação; Michel Pêcheux; Persépolis.

MARJANE SATAPRI E ILUSTRAR EL ARTE DE: DISCURSO HISTÓRICO Y AUDIOVISUAL

Resumen: el tratamiento de los efectos y la estética sonora de la película de animación Persépolis con el trailer disponible en Internet. El video está basado en la novela gráfica producida por iraní Marjane Satapri través de los cómics - libros de historietas para el público adulto. Analizamos la memoria a través del discurso utilizado por el autor, se convierte en personaje de su historia, habla de su infancia durante la Revolución Islámica. Historia de refugio y la represión.

Palabras clave: Análisis del Discurso; Animación; Pêcheux; Persépolis.

\section{MARJANE SATAPRI AND ILLUSTRATE THE ART OF: HISTORICAL SPEECH AND AUDIOVISUAL}

Abstract: treating the effects and sound aesthetic in animation film Persepolis with the trailer available on the internet. The video is based on the graphic novel produced by Iranian Marjane Satapri through comics - Comic Books for adult audiences. We analyzed the memory through discourse used by the author, becomes character of its history, discusses her childhood during the Islamic Revolution. History of refuge and repression.

Keywords: Discourse Analysis; Animated film; Pêcheux; Persepolis. 


\section{INTRODUÇÃO}

Existe uma combinação do cinema com a HQ, é o impresso virando vídeo, é a imagem ganhando uma dimensão maior através da recepção que o filme provoca. Existem poucas pesquisas científicas que tratem das Revistas em Quadrinhos (HQs) e do cinema de animação, principalmente se levarmos em consideração a existência da relação entre elas. O cinema depende da comunicação midiática e o público não admite filmes sem efeitos sonoros. O filme estreou em 2008 na França, sendo leal a história de Persépolis em seu personagem criado nos quadrinhos. A voz do narrador, o diálogo da personagem com familiares e pessoas que a própria autora se identificava, convivia, são marcantes no vídeo. A música nos faz sentir triste, existe uma conexão das imagens, sons e diálogos que nos fazem participar com maior emoção desse momento histórico tratado em um filme de animação. Permite-nos voltar ao tempo e viver aquele momento de dificuldades e abusos de poder dessa época.

Na relação entre linguística e a história podemos buscar a Análise de Discurso (AD) com Michel Pêcheux ${ }^{29}$ para apropriarmos de nosso objeto de estudo - o personagem Persépolis. Pêcheux (1983) considera que através da análise do movimento discursivo podemos compreender que o discurso nos permite - que um lugar particular em que tal relação ocorre - possamos explicitar mecanismos da determinação histórica que estão no processo de significação. A textualização do político pode ser trabalhada através da AD e nos permite compreender as relações de poderes em seus significados vividos pelo personagem e que fazem parte da vida de muitas mulheres naquele momento de opressão. Simbolicamente percebemos o destaque das preocupações e finalidades da autora que estão presente ao fazermos uma $A D$ e que podemos fazer um julgamento mais reflexivo ao tratarmos os estudos de Michel Pêcheux.

O registro histórico está presente no formato do filme Persépolis, codificando som e imagem. Fatos reais são contados através de histórias em quadrinhos que é mediado para esse vídeo trailer que se torna uma comunicação tecnológica. Evolução digital que nos faz refletir sobre a estética sonora usada na comunicação. A percepção dos usuários passa a ser mais 
efetiva quando a arte e a estética são trabalhadas na imagem comunicacional com o avanço tecnológico. Evolução tecnológica que usa o meio digital. Permite-nos imaginar e reagir através da imagem em movimento. Para Aumont (1994:21) “o importante neste ponto é observar que reagimos diante da imagem fílmica como diante da representação muito realista de um espaço imaginário que aparentemente estamos vendo." O autor trata da questão da profundidade que permite ao espectador perceber a imagem, uma impressão que já faz parte do nosso cotidiano, seja na TV ou no cinema. Ainda, afirma que "mais precisamente, como a imagem é limitada em sua extensão pelo quadro, parece que estamos captando apenas uma porção desse espaço. É essa porção de espaço imaginário que está contida dentro do quadro que chamaremos de campo." Impressão do espaço real que é produzido pela imagem fílmica e quando produzido em preto e branco como o filme de Persépolis - nos permite aumentar o imaginário já que hoje estamos acostumados com a presença das cores. A AD permite essa prática de leitura que podemos fazer no audiovisual buscando a cultura implícita ou explícita que está nessa montagem de dispositivos e presente na linguagem tratada no cinema. Relacionamos o real com o imaginário. Consente-nos localizar o que o espectador não consegue localizar. Conseguimos fazer uma leitura da verdade tratada no imaginário do vídeo. Analise de uma montagem fílmica que abrange a conscientização cultural de determinada época e sociedade. AD que nos permite ir além do audiovisual do vídeo ao analisarmos a relação do simbólico e do linguístico dentro de um movimento arraigado de fundamento cultural.

\section{DISCURSANDO A HISTÓRIA EM QUADRINHO DE MARJANE PARA O AUDIOVISUAL}

Compreendemos que existe necessidade de um conhecimento mínimo sobre o que aconteceu na década de 1970 no Irã para analisarmos com maior precisão o filme Persépolis. A autora, Marjane Satrapi, viveu essa revolução do regime xiita, assistiu um povo cansado da intensa opressão realizada pelo governo. População persa que busca seus direitos de liberdade. Liberdade essa que ainda se torna extensa nas brigas das mulheres, em uma segunda revolução, que são obrigadas a utilizarem o véu islâmico. Xá Rheza Pahlevi conseguiu modernizar o país, foi um governo ditatorial e que tinha apoio da União Soviética, mas de forma opressiva não aceitava a oposição dos xiitas 
que não seguiam a religião católica e dos democratas que defendiam seus direitos de liberdade no país. De acordo com dados do Instituto de Relações Internacionais da PucRio ${ }^{30}$ :

O atual Irã, a antiga Pérsia, é sem dúvida fruto da colonização pelas potências européias, que alienaram as forças religiosas por meio da instauração de um regime aliado aos interesses ocidentais, mas que negligenciavam as pressões sociais internas. Com um descontentamento crescente, era previsível a revolta contra o modernizador Xá Rheza Pahlevi que ocorreu em 1979 por meio da articulação do Aiatolá Khomeini e a posterior instauração de um regime conservador, que inclui o Islã em todas as esferas públicas e privadas da vida em sociedade. Em 2000, parece que a vontade popular começou a mudar de rumo, ao eleger uma maioria liberal para o Parlamento, o que vai de encontro a políticas como a polícia religiosa que atua no país bem como à Liderança Suprema, atualmente exercida pelo Aiatolá Khamenei. Mais uma evidência da insatisfação popular com o governo ultra-conservador em voga no país foram as revoltas contra a reeleição do Presidente Mahmoud Ahmadinejad, especialmente pelos eleitores jovens. Vale ressaltar que o Irã é nesse momento o maior, se não o único, exemplo de Estado regido por um governo no qual o Islã é a maior força política. Isso fica claro no sistema Executivo iraniano, no qual o Líder Supremo é a escala mais alta na hierarquia do poder e comanda a Assembléia dos Especialistas, que também um organismo importante formado por ulemás e outros especialistas religiosos. Por fim, o Conselho dos Guardiões é um terceiro organismo criado após a Revolução que, junto aos outros dois, pode vetar não só os presidentes eleitos como também os candidatos à presidência. Em suma, as instituições eleitas pelo voto direto, dentre as quais a Presidência é a mais importante, são seriamente limitadas pelos órgãos religiosos provenientes da Revolução Islâmica que tornou o Irã a teocracia mais bem sucedida atualmente no mundo, especialmente no mundo muçulmano. (p.5)

De acordo com Gomes (2007) o intelectual europeu - podemos notar nos amigos e parentes de Marji cheganda da Europa - deu força ao "sentimento revolucionário" de uma geração de jovens, milhares de estudantes, que enxergavam na figura do Shãh um homem opressor e aderente aos interesses internacionais.

30 Instituto de Relações Internacionais da PucRio. Islã e política - o caso de Turquia, Marrocos e Irã. Aluna: Gabriela Russo Lopes. Orientador: Nizar Messari. Pontifícia Universidade Católica do Rio de Janeiro. Rio de Janeiro, 2007. 
Figuras 01-02: Fotos da capa da Revista em Quadrinhos e do filme Persépolis ${ }^{31}$
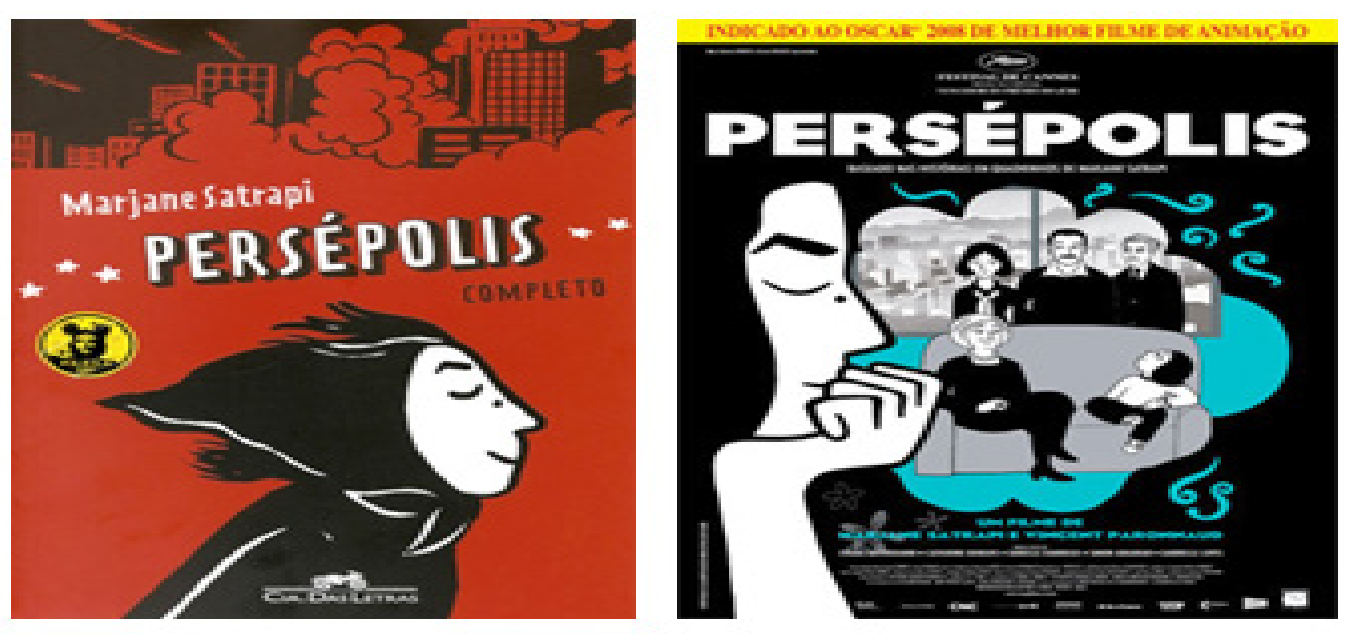

Fonte: Revista e filme de Persépolis

Com base nas Histórias em Quadrinhos (HQs) Persépolis (fig.01) e no filme Persépolis (fig.02), em 1978 no Teearão os familiares da personagem Persépolis - no filme chamada por Marji - juntavam com amigos e faziam festas com bastante bebida e música desde quando ela era criança, algo que era proibido pelo governo. Festas animadas, mas que também serviam para levantar questões de sofrimentos e opressão de amigos e parentes presos injustamente por não acatarem o regime político, como o tio de Marji que há mais de quatro anos estava preso em uma longa promessa do governo em libertá-lo. Pessoas que não perdiam a esperança de um dia esse regime terminar, "não durará muito tempo, vai haver uma enorme revolta" (frase dita pelo pai de Persépolis no filme).

O filme mostra que o tempo toda a família de Marji não aceitando o regime islâmico. Os produtos estrangeiros são um refúgio, principalmente, para Marji. Frases são ditas com constância no filme comprovando essa fulga da guerra em um modo de vida estrangeira. Os pais de Marji e sua avó recebem em casa um parente chegando de Paris, dizendo como "adorava batatas fritas com Ketchup e filmes do Bruce Lee... usava tênis Adidas... era um tempo que existia dignidade naquela população."

31 Fig. 01: SATRAPI, Marjane. Persépolis. Tradução Paulo Werneck. Cia e Letras, 2007. Fig. 02: Persépolis. Escrito e dirigido por Vicent Paronnaud e Majane Satrapi. França: Estúdio 2.4.7 Films, Coproducion Avec France 3 cinéma e association Company avec ceuuloid Dreams Sony Pictures Classics sofica soficinema ET sofica Europacorp. Estréia: 22 fevereiro de 2008. 1 DVD (95 min), preto e branco. Amimação. Título original: Persépolis. 
Persépolis no filme lê uma carta para sua avó, dizendo: “eu, marjane, futura profetiza, decidi que: primeiros todos devem ter um bom comportamento. Segundo, todos devem dizer boas palavras. Terceiro, todos devem fazer uma boa ação. Quarto, os pobres devem poder comer um frango frito todos os dias. Quinto, nenhuma mulher idosa sofrerá novamente." Sua avó diz que será sua discípula se realmente colocar tudo que está falando em prática, afirmando que a população não sofrerá mais.

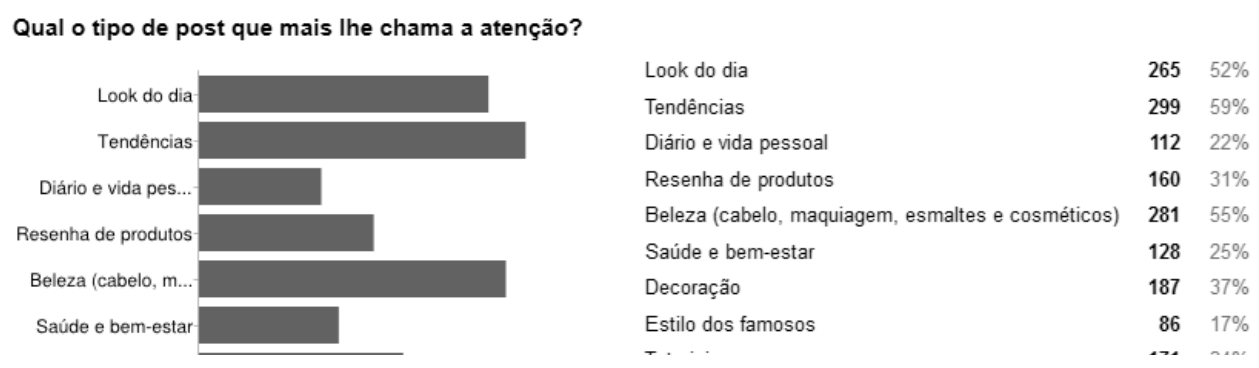

Figuras 03-04: Fotos do filme Persépolis ${ }^{32}$

A menina diz que para colocar tudo em prática basta ser proibido para acontecer. O que nos mostra que ainda era uma criança inocente, afinal a guerra do Irã ocorria exatamente por essa falta de liberdade. Vivia no meio de uma guerra sem ter noção do que realmente representava. Ela era feliz por ter a inocência de uma criança, tinha o carinho e atenção de seus pais e avó mesmo na guerra. Nesse mesmo momento acontece uma passeata (fig.03) do lado de fora, uma multidão de pessoas pedindo a morte de Shãh. O pai da personagem Marji chega gritando que aquele "é um momento histórico", levantando a criança (fig.04) para o alto em um momento de conseguirem adquirir novamente a liberdade em seu próprio país. O filme vai e volta no tempo, tratando a criança e a adolescente Marji em um momento de repressão da sociedade iraniana.

Buscando Pêcheux (1995: 163), para o teórico pode-se "precisar que a interpelação do indivíduo em sujeito de seu discurso se efetua pela identificação”, ou seja, do sujeito, “com a formação discursiva que o domina”, que logo o mesmo é constituído como sujeito. Identificação, que considera ser uma identificação, que vem do imaginário, fundadora da unidade do sujeito.

32 Fig. 03-10: Persépolis. Escrito e dirigido por Vicent Paronnaud e Majane Satrapi. França: Estúdio 2.4.7 Films, Coproducion Avec France 3 cinéma e association Company avec ceuuloid Dreams Sony Pictures Classics sofica soficinema ET sofica Europacorp. Estréia: 22 fevereiro de 2008. 1 DVD (95 min), preto e branco. Amimação. Título original: Persépolis. 
Para o autor "os elementos do interdiscurso" - "pré-construído" e "discurso de sustentação" - o que "constituem no discurso do sujeito, os traços daquilo que o determina, são reinscritos no discurso do próprio sujeito. Tratando o filme de Persépolis, os pais de Marji imaginavam uma liberdade não existente e difícil de ser alcançada através de um novo governo. O discurso usado pela professora de Marji era tão forte que criava um refúgio da criança na busca de Deus, a criança acreditava que Shãh era uma escolha religiosa.

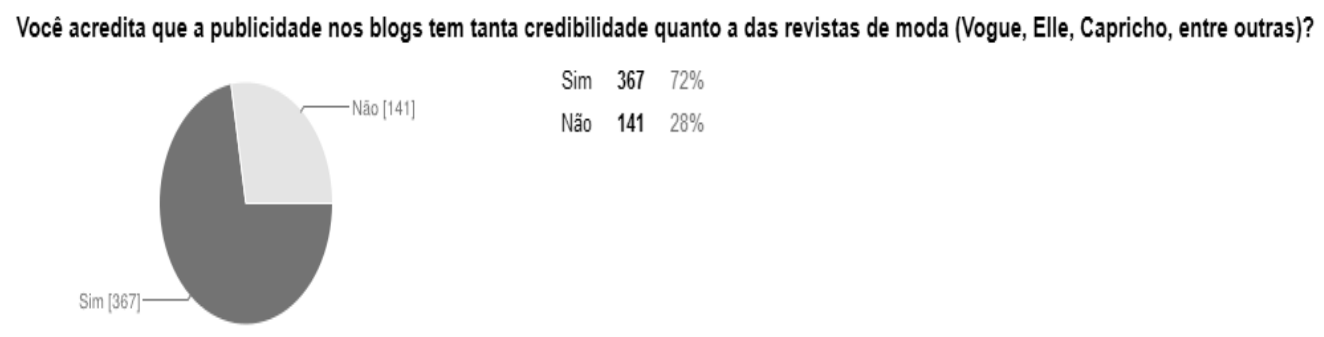

Figuras 05-07: Fotos do filme Persépolis

Frases como "depilar as pernas e me tornar a última profetiza" faziam parte do contexto dessa família que não mediam as palavras pela vontade de ganhar liberdade, frases ditas ao lado de Persépolis, criança que vivia sempre ao meio das conversas desses adultos. Diziam que um dia o Shah ainda pagaria por esse mal causado a tantas pessoas que não aceitavam essa opressão injusta, minoria que pagava pela luta de liberdade do povo. A menina Marji nesse momento da conversa diz que gosta de Shãh e que é uma escolha de Deus. Algo que foi o próprio Deus que lhe disse como também a professora, o que deixa a família silenciosa naquele momento. Em seguida, seus pais explicam a Marji que é tudo mentira e que não foi escolha de Deus. O pai de Marji explica contando a história de seu país no filme Persépolis:

A verdade é que, há 50 anos o pai do Shãh, um oficial, quis destronar o imperador Qadjar, seguirei os passos de Ataturk! Vou modernizar o páis, e vou criar uma República!Mas isso chegou aos ouvidos dos Ingleses. Bom Dia! Por que quer criar uma República? Você poderia ser Imperador!Eu Imperador? Claro! É melhor do que ser Presidente. Você terá poderes absolutos. Um país como o seu, precisa de alguém forte como você para o governar. Isso é verdade. Além disso, sabia que o Clero é contra a República? Cá entre nós, eles têm razão. O que devo fazer? Nada. Você nos da o petróleo e nós cuidaremos do resto. Agora eu sou o rei! Tudo que pertence à vocês é meu. Ele era um babaca! (Diz Marji interrompendo a história do pai). Sim e não. Ele era um ditador, mas modernizou o Irã. Continuando a história... Ele adorava o seu país, ao contrá- 
rio do seu filho, o seu sucessor. "Agora eu é que sou o rei! Sou a luz dos Arianos! Vou tornar este país o mais moderno de todos os tempos! O nosso povo vai recuperar o seu esplendor!" (Diz o filho substituto) Sim, o pai do Shãh foi muito severo. Ele mandou o seu avô para a prisão. Mas o seu filho foi dez vezes pior. Vovô esteve na prisão? (Pergunta Maji) Sim! Ele era membro da família real. Ele era um príncipe Qadjar. O pai de Shãh tirou tudo dele. Ele foi para prisão porque era comunista.
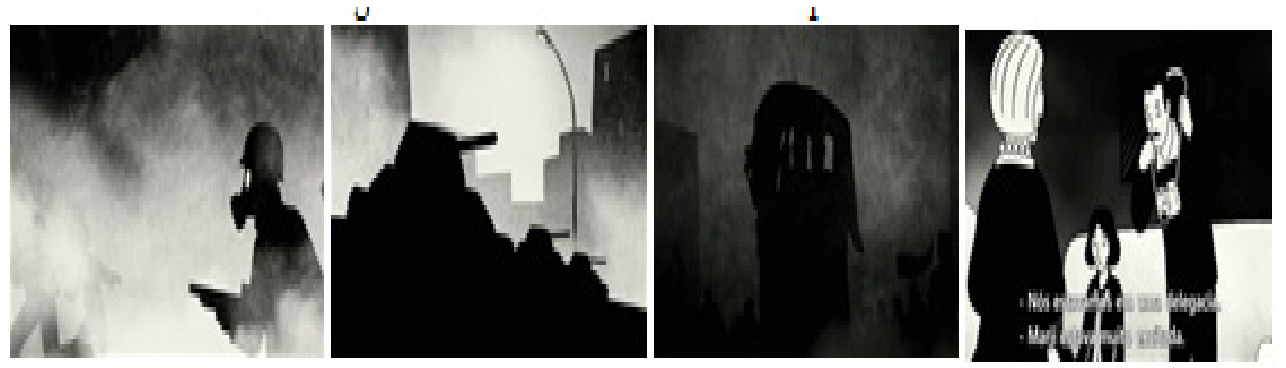

Figuras 08-11: Fotos do filme Persépolis

Na história do pai de Marji notamos a influência inglesa sobre o Irã, com claro interesse no petróleo iraniano. Os governos 33 Shãh e em seguida do filho Mohammad Reza Pahlavi, que foi o último príncipe herdeiro do antigo Estado Imperial do Irã. Shãh teve ajuda do governo britânico e americano para modernizar o país. O filme mostra os comunistas (fig.08 e 10) nas ruas lutando pela liberdade, os soldados e canhões de guerra atirando e matando quem estava contra o governo. Notamos a participação dos pais de Marji (fig.11) nessa revolução contra o novo sucessor de Shãh. Nesse momento seus pais chegam da rua dizendo que por sorte não tinham sido capturados e que os soldados haviam pegado os negativos da máquina fotográfica. Essa luta de classes do proletariado é tratada no filme, sendo Che Guevoro ${ }^{34}$ no comando.

Ao conseguir derrubar Shãh os comunistas acreditam que tudo iria meIhorar, quando somente piora a situação. Ocorre uma nova revolução, porém, agora passa a ser uma revolução religiosa. Ruhollah Khomeini, líder espiritual e político, passou a representar a sociedade iraniana. Religião xiita iraniana na Revolução Iraniana em 1979. Gomes (2007) afirma que Khomeini “protagonizou a despersonificação do xiismo, isto é, a centralidade da lei

33 Mohammad Reza Shãh Pahlavi (1919-1980) conhecido por Shãh. Filho de Shãh: Mohammad Reza Pahlav (1966-2011).

34 Ernesto Che Guevara (1928-1967) nasceu na Argentina, revolucionário e marxista 
religiosa substituiu a da pessoa religiosa. Os ritos de instituição e os aparatos de representações hegemônicas estão voltados para sacralização da política e do governo sob a égide do Corão." (p.6) Ressalta o predomínio da fé que serve como um caminho revolucionário aproximando a modernidade e a simbologia xiita.

Passou a existir uma aliança política de dominação religiosa. As posições de classes brigam pelos seus direitos de escolha, conflitos que se tornam maiores ao relacionar a representação religiosa. Pêcheux (1995) afirma que o discurso materializa o ideológico, reforça ao considerar que o processo discursivo tem como base a língua influenciada pelas classes. A subjetividade é interligada ao processo de produção de sentidos, que tem relação da constituição do sujeito e do sentido. Notamos no decorrer do filme de Persépolis que existem palavras que fazem o mesmo sentido para sociedade, independentemente da idade ou da classe social. Mas, de acordo com o seu contexto ela muda de sentido para o sujeito. Como o caso de Marji afirmar que Deus é que quis Shãh no governo. Mas, quando na verdade, existiu um contexto da professora tratado em sala de aula com Marji. "Mascarou", de acordo com Pêcheux (1995:160), o que realmente diz, existe uma "transparência da linguagem" quanto "ao caráter material do sentido das palavras e dos enunciados". A formação ideológica da população tem todo um processo sócio-hitórico que influenciam nas expressões e proposições das palavras produzidas.

A música complementa as imagens (fig.08-11) do filme Persépolis nesse momento dramático vivido pela população islâmica. Percebemos uma perspectiva muito maior a partir da denúncia na obra de Adorno (1970), busca a sociedade atual para tratar e justificar a manipulação da produção artística tanto ao combate dos recursos ideológicos quanto capital. A sociedade livre que logo acredita em um novo mundo através das mudanças necessárias em uma visão de urgência e de pessimismo. A estética está nessa "administração" do mundo e o lugar que o mesmo atribui ou aplica à arte. Mesmo que o autor trate da contemporaneidade, podemos buscar o filme Persépolis e verificar que o filme de Persépolis busca a história sócio-cultural e política vivenciada pelo Irã tratando questões estéticas vividas na vida real pela autora Majane Satrapi, "um protesto constitutivo contra a pretensão à totalidade do discursivo" (p.117). A forma e conteúdo do filme conseguem trazer elementos de protesto. O filme consegue dialogar com sociedades que viveram ou não naquela época. A arte consegue renovar e informar conhe- 
cimentos passados dentro de uma indústria cultural atual, ou seja, o filme. Audiovisual que através da estética valoriza a cultura popular de diferentes povos.

Adorno (1970) considera que valorizar a arte popular é denunciar e ao mesmo tempo mostrar uma resistência integrada aos interesses econômicos que estão presentes na indústria cultural. O filme de Persépolis está inserido nesse meio da indústria cultural, mas ele representa algo muito mais artístico com caráter de denuncia do que financeiro e econômico. Ele realmente estuda a natureza do belo, busca a estética em sua percepção e sensação de uma sociedade sofrida que buscou e imaginou adquirir a liberdade. A produção das emoções está exatamente no contexto artístico da estética, uma criação da realidade em forma de audiovisual. A opressão tem seus momentos de privação da beleza, como os véus de uso obrigatório das iranianas.

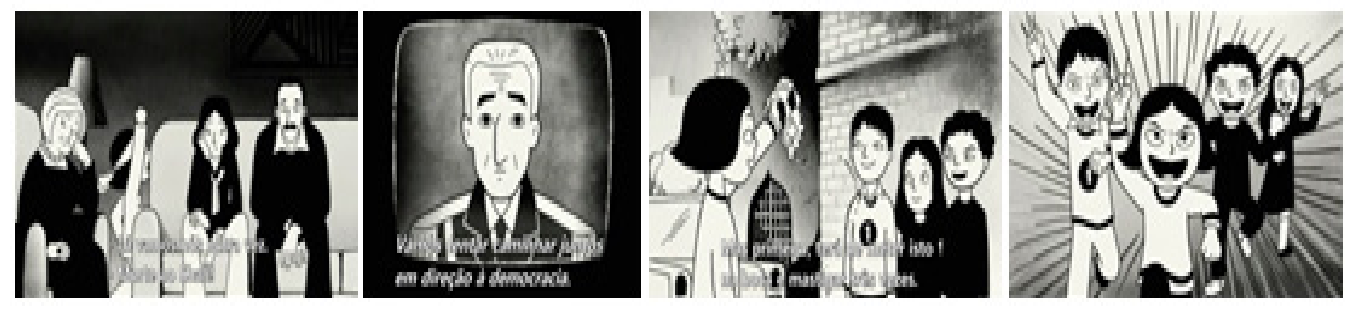

Figuras 12-15: Fotos do filme Persépolis

No filme de Persépolis, na imprensa apareciam os oficiais (fig.13) com discursos que demonstravam compreender a revolta do povo, chamando a população para caminharem e construírem juntos em direção a democracia.

A autora Marjane consegue passar para história do filme na sua vida de criança, com momentos de alegria ao lado dos familiares. Brincava pedindo a morte de Shãh (fig. 12) por não ter noção da gravidade do assunto e ao mesmo tempo levava a sério o que ouvia nas conversas dos adultos para as brincadeiras de criança, como frase: quem perder será torturado até a morte... colocar lixo na boca e mastigar (fig.14)... Ou mesmo passam a querer que Ramine, filho de um dos membros dos serviços secretos do Shah, paguem pelos erros de Shah. Seu pai matou vários comunistas o que faz do filho um vilão aos olhos daquelas crianças. Novas frases são ditas por essas crianças com pregos nas mãos (fig.15), como: arrancar seus olhos fora". 


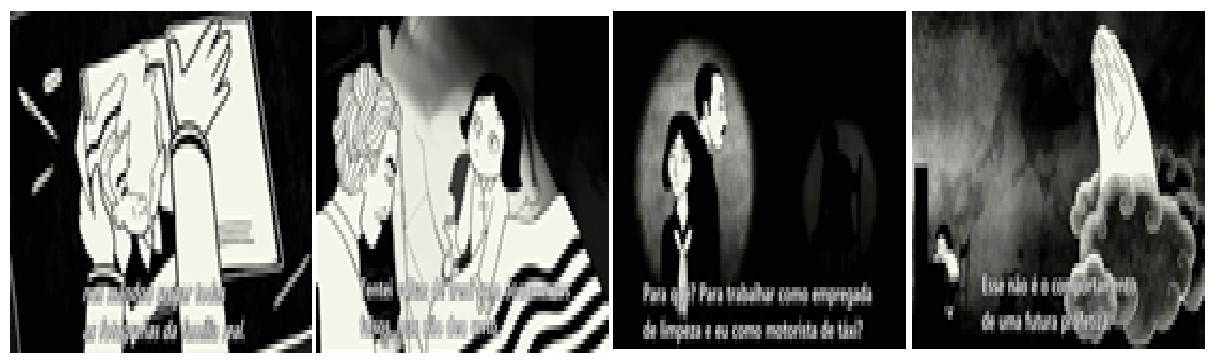

Figuras 16-20: Fotos do filme Persépolis

Voltando a família de Marji, seu tio Siamak sai da prisão - logo, uma frase da prima Marji dizendo que ele é um herói, fala orgulhosa do pai - a autora do filme expressa momentos difíceis vivenciados pelo tio, como as torturas realizadas por "cientistas que conheciam muito bem o corpo humano. Eles sabiam bater onde doía mais... choques com cabos elétricos enormes. O meu pé já não se parece com um pé. E porque meu pé? Porque há nervos que vão diretamente do cérebro aos pés" É uma dor indescritível. Os que nos torturavam tinham sido treinados pela CIA. Então na vanguarda em tudo o que diz respeito a tortura... chicoteado com cabos elétricos..."

Conversa sobre os membros da guerrilha, como Hamid que foi preso e assassinado, fizeram sua vida um inferno, sofrendo as piores torturas. No caso de um que "tinha cianeto com ele, mas infelizmente não conseguiu usar".

O filme trata de toda a sociedade se considerando comunistas durante meses com a partida de Shãh. Os professores que eram admiradores de Shah pede para os alunos rasgarem (fig.16) todas as fotos deles. Os encontros políticos eram cada vez maiores e os comunistas viraram heróis. Seu Tio Anouche (fig.17) que fazia parte desse movimento tinha certeza que tudo iria mudar para melhor e que nada poderia deter o povo com uma sociedade livre e justa. Esse tio havido estado na prisão mais tempo que o pai de Laly o que para Marji era um orgulho. Era o fim da ditadura, mas o proletário não iria reinar e ter liberdade como esperavam, pensavam que nada poderia ser pior que o controle do governo Shãh. A autora Marjane resume a história antes e até aquele momento vivido por Anouche ao conta-la para a personagem Marji, assim: 
"Eu tinha 18 anos quando o meu tio e os seus amigos proclamaram a independência da província do Azerbeijão. Fereydoun nomeou-se a si próprio ministro da justiça dessa República. A justiça é a base da democracia. Todos os homens são iguais perante a lei." Anouche se tornou secretário buscando libertar o Irã da ditadura de Shãh. Seu pai era leal ao Shãh e dizia que iria acabar todos mortos. E estava certo, Fereydoun foi morto e teve que fugir, não poderia evitar a morte. Enfrentou tempestades, passou fome e frio. Refugiou-se em Astara, casa dos pais, mas partiu, precisava se exilar, chegando a União Soviética, foi para Leninegrado, depois para Moscow onde completou seu doutorado em Marxismo-Leninismo. Mas, com saudade da família volta ao Irã, onde acaba prezo. Agora, depois de nove anos foi solto com a saída de Shah. Os heróis de Marji são retratados no filme, como Fereydoun. Tio que a pede para não esquecer a memória da família. Entregou um patinho feito de migalhas de pão que havia feito na prisão.

Logo, começam algumas famílias a saírem do país com medo, comunista são mortos. No filme nos mostra esse período de transição da revolução durou pouco já que grande parte da sociedade é analfabeta. Somente a ética religiosa ou o nacionalismo podem reunir as pessoas. Os pais de Maji não queriam sair do Irã, não queriam cair o padrão de vida que tinham em seu país trabalhando com faxina ou dirigindo taxi, mas ao mesmo tempo não queriam que suas filhas ficassem em um país opressor e ditador.

Ao tratarmos Adorno (1970) percebemos que a sensibilidade bem do entendimento do sentido dado pela dimensão do conhecimento. Experiência estética que percebemos que ao conhecermos a história da Irã conseguimos compreender com maior precisão o filme. A sensibilidade é complementada pela música que o tempo todo nos passa uma sensação de nostalgia e compaixão. A arte não é apenas intuição ela se desvia e apenas sobrevive com a síntese. Lembranças que nos permite um momento racional e que a arte passa a ser um entendimento coletivo, universal. O sujeito invade o coletivo trazendo sua experiência do verdadeiro. Se buscarmos as ideias de Adorno associadas ao discurso de Pêcheux (1995), percebemos que conhecimento individual está na necessidade do sujeito de acordo com a sua cultura, engloba totalidades e controle que ocorrem de acordo com a ação do sujeito (Persépolis). A organização do filme nos coloca reticências sobre o assunto, mas também existe uma opinião formada com fim sobre a necessidade e desejo da população iraniana. O enunciado das HQs (fig.21-28) e do filme Persépolis (fig.02-20) nos coloca linhas definidas e regulariza nosso pensa- 
mento sobre o assunto.

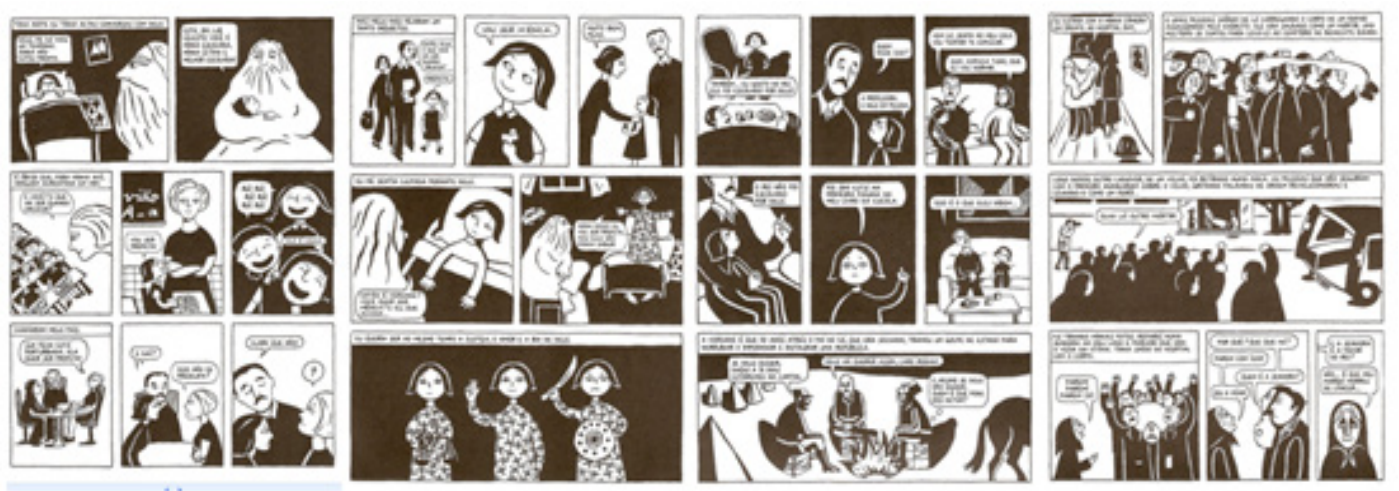

Figuras 21-24: Fotos da Revista em Quadrinhos Persépolis
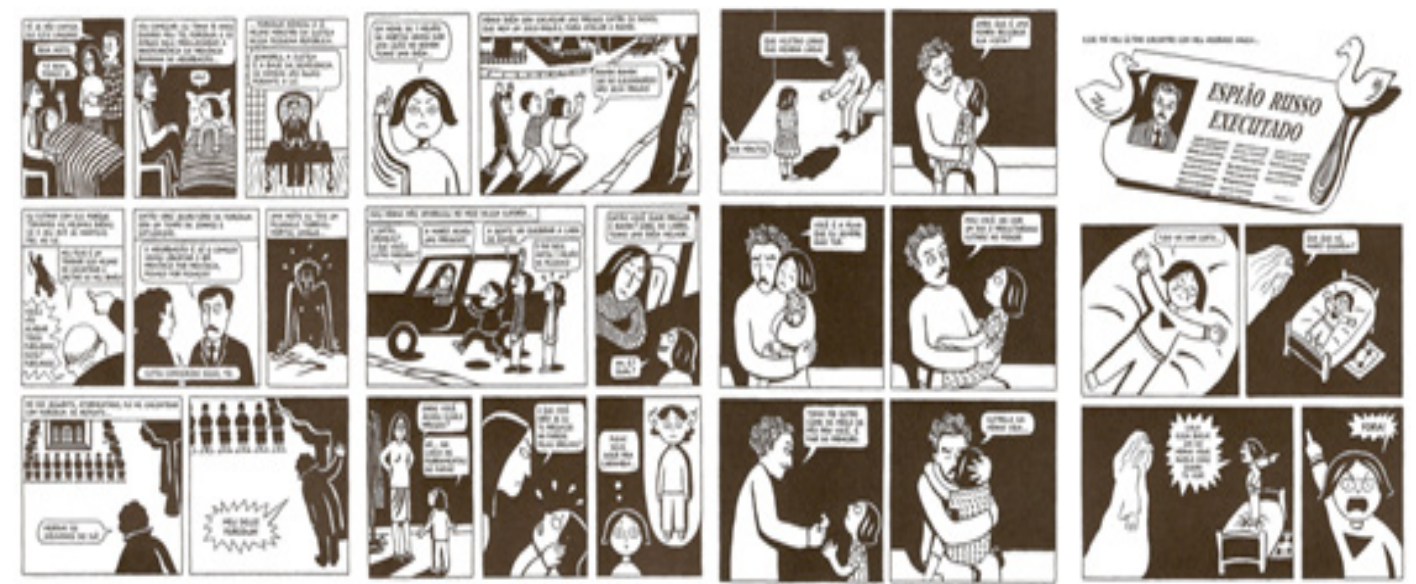

Figuras 25-28: Fotos da Revista em Quadrinhos Persépolis

Marji sempre conversa com Deus no filme (fig.20), o que podemos notar que também foi retratado nas Histórias em Quadrinhos (fig.21, 22 e 28). Trata do seu mau comportamento e o fato que ainda não esteja preparada para ser profetiza. Busca tratar momentos de dúvidas do que era certo ou errado, confronto de opiniões quanto aos deveres e direito de liberdade em uma mistura religiosa e política.

Os heróis de Marji, com o tio Fereydoun no filme (fig.17) e nas HQ (fig.2124). Na Revista em Quadrinhos (HQ), edição completa dos 4 volumes das HQ Persépolis em edição completa, por Marjane Satrapi, resume bem na fala de Marji: “Na minha família tem muitos heróis, meu avô já foi preso. Meu tio Anuch também: 9 anos! Ele até foi para a União Soviética. Meu tio-avô Fereidun proclamou um Estado democrático, depois foi...". O sofrimento vivido por Marji fica estampado no filme no momento que seu tio é prezo 
(fig.27), em seguida, seu herói é morto (fig.28), informação que é divulgada pela mídia como um "espião russo executado". Nesse momento Marji briga com Deus (fig.28) que não fez nada para evitar a trajédia.

A mídia divulga que o novo governo irá se livrar de todos os anti-revolucionários e ao mesmo tempo nos faz enxergar que é naquele momento que realmente começa a guerra. O véu na sua adolescência (fig.32-33) era motivo de descontração com as amigas, tudo era motivo para rir, como é contado pela Majane Satrapi.
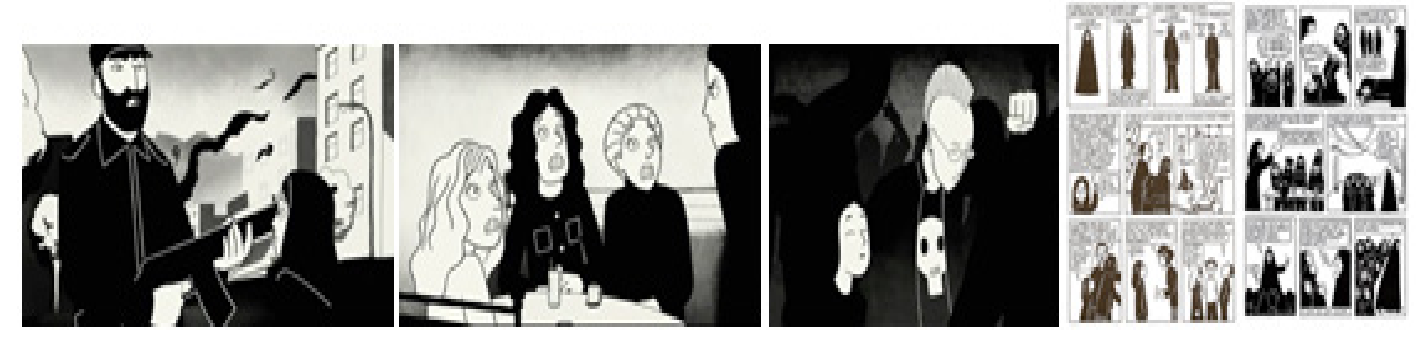

Figuras 29-31: Fotos do filme Persépolis. Figuras 32-33: Fotos da HQ Persépolis

Marji cresce e passa a viver o momento político religioso, onde as muIheres são obrigadas a usar véu nas cabeças (fig.29, 32, e 33). Podemos notar a personagem Marjane ou Marji no filme Persépolis em sala de aula ao lado de outras meninas, também islâmicas, na província de Teearão no Irã, com o véu em suas cabeças, mesmo que tivessem apenas mulheres nas salas. Marji, influenciada pela personalidade dos familiares, em especial sua avó, levanta no meio de uma palestra de obrigações aos estudantes da escola que estudava e diz que pensa quanto ao uso do véu, a liberdade.

Ao sair do seu país notamos o destaque nas diferenças culturais (fig. 3031), de seu país, da música ao estilo de vida. Existem momentos que Marji se sente confusa com o que é dito pela TV e o que é dito pela família, ora frases de opressão, ora de direito a liberdade. Pêcheux (1983) questiona o sujeito do enunciado tratando o ganho, busca as eleições para trata a perspectiva de quem realmente ganhou, colocando duas populações, a que acredita que realmente há uma vitória e aqueles que a vitória já virou uma crença inexistente vivendo na esperança de acontecer um movimento popular. A linguagem é estruturada e consequentemente o pensamento é sistematizada. Temos dependência das coisas. Depois que Marji passa a se encontrar em liberdade em outro país percebe que existem outros fatores que a impede de ser feliz, como a distância da família, os preconceitos raciais vividos por ela nesse novo mundo. Percebe a necessidade de ter orgulho de ser quem é (fig.30) e deixar claro que não aceita mais repressão (fig. 29) como vivia em 
seu país.

\section{CONCLUSÃO}

Percebemos nas cenas do filme de Persépolis a forte denúncia sobre a censura governamental vivida pela população iraniana. A falta de liberdade, desde festas, veste, modos de vida a opção religiosa. O rígido e incomplacente controle estatal do qual Marji vive durante sua infância e adolescência no Irã, ou mesmo, quando volta e tem suas malas revistadas verificando se levava algo que não pudesse ser usado pela população iraniana. A censura tenta tirar a percepção de outras identidades e forma de vida de outros países que pudessem atrapalhar o controle governamental. Khomeini passa a colocar o uso do véu como obrigatório que afirmava ser um meio de proteção a mulher contra o desejo do homem. As imposições da veste feminina nos mostram a busca de Marji pela igualdade vivida no discurso do filme. Persépolis busca liberdade em outro país, mas não consegue se desvincular de sua identidade. Ao sair do Irã, ainda não consegue sentir-se liberta. Ocorre exclusão e preconceitos vividos que a faz pensar ainda mais em suas origens. Notamos uma ponte de diálogo e discurso entre elementos orientais e ocidentais a partir do filme de Persépolis, uma construção entre culturas que padronizam o comportamento e identidades locais, mas que também têm os seus momentos globais, proporcionados pela mistura de hábitos, como alimentação.

\section{REFERÊNCIAS}

ADORNO, Theodor W. Teoria Estética. São Paulo: Martins Fontes, 1970

AUMONT, J. O filme como representação visual e sonora. In: A estética do filme. 2. Ed., p.19-52. Campinas: Papirus, 1994.

GOMES, Eduardo Teixeira. A revolução iraniana na perspectiva de Khomeini: representações e paradigmas de um governo islâmico xiita (1979-1989). Dissertação apresentada ao programa de pós-graduação em História Social das Relações Políticas da UFES. Universidade Federal do Espírito Santo. Vitória, 2007.

PÊCHEUX, M. O discurso: estrutura ou acontecimento. Trad.: Eni Pulcinelli Orlandi Campinas: Pontes, 1997. Edição original: 1983.

PÊCHEUX, M. Semântica e discurso: uma crítica à afirmação do óbvio. 2. Ed. Campinas: UNICAMP, 1995.

SATRAPI, Marjane. U.S trailer: Persepolis. This is the U.S. trailer for Persepolis, directed 
by Vincent Paronnaud and Marjane Satrapi. Sony Pictures Classics. EUA: Winner - Festival de Cannes, 2007. Video URL: <http://www.imdb.com/video/imdb/vi280101145/> Acesso em: 10 Julho de 2012.

SATRAPI, Marjane. Persépolis. Tradução Paulo Werneck. Cia e Letras, 2007.

SATRAPI, Marjane; PARONNAUD, Vicent. Persépolis. Escrito e dirigido por Vicent Paronnaud e Majane Satrapi. França: Estúdio 2.4.7 Films, Coproducion Avec France 3 cinéma e association Company avec ceuuloid Dreams Sony Pictures Classics sofica soficinema ET sofica Europacorp. Estréia: 22 fevereiro de 2008. 1 DVD (95 min), preto e branco. Amimação. Título original: Persépolis.

\section{Eliane Meire Soares}

Doutora em Comunicação Social na PUCRS. Profa. Pesquisadora da UEMG. Coordenadora do Grupo de estudo GEDID: Design da Imagem e seus Discursos na PUCRS. Este artigo é resultado de pesquisa do GEDID.

\section{Janie Kiszewski}

Doutoranda em Comunicação Social na PUCRS. Professora na Escola Superior de Propaganda e Marketing - Sul desde 2001. Pesquisadora do Grupo de estudo GEDID.

\section{Tammie Caruse Faria}

Doutoranda em Comunicação Social na PUCRS. Jornalista do quadro técnico-administrativo em educação da Universidade Federal do Rio Grande (FURG). Pesquisadora do Grupo de estudo GEDID: Design da Imagem e seus Discursos na PUCRS.

RECEBIDO EM: 22/09/2014

APROVADO PARA PUBLICAÇÃO: 06/10/2015 